\title{
Utilization of Acetate in the Human Forearm during Exercise after Ethanol Ingestion
}

\author{
F. Lundquist, L. Sestoft, S. E. Damgaard, J. P. Cllausen, and \\ J. Trap-Jensen \\ From The Department of Biochemistry A, University of Copenhagen, The \\ Department of Biochemistry, University of Odense, and The Department of \\ Clinical Physiology, Frederiksberg Hospital, Copenhagen, Denmark
}

\begin{abstract}
A BSTRACT The uptake of acetate in the human forearm was studied in five fasting ( $14 \mathrm{~h}$ ) subjects during $10-\mathrm{min}$ periods of ergometer work at 7 and 10 kilopond-meters per minute $(\mathrm{kpm} / \mathrm{min})$. A constant arterial acetate concentration was established by administration of a small quantity of alcohol ( $25 \mathrm{~g})$ to the subjects after a control work period. Blood flow was measured by an indicator dilution technique. Acetate uptake varied linearly with the product of arterial acetate concentration and blood flow. Acetate metabolism was calculated to account for about $6.5 \%$ of the energy metabolism, assuming complete combustion to carbon dioxide and water. Oxygen uptake and blood flow did not change in the presence of acetate and ethanol.

After administration of ethanol the arterial concentrations of FFA and glycerol decreased to about half, whereas the lactate concentration increased to about twice the control values, confirming other reports.

Glucose utilization was increased and lactate output decreased during the ethanol periods, presumably a consequence of the changing arterial concentrations and increased insulin level. Measurements of the arterial and venous lactate/pyruvate concentration ratios indicate that the NAD-mediated cytoplasmic redox state in the muscle is not changed in the presence of acetate and ethanol.
\end{abstract}

Received for publication 25 April 1973 and in revised form 10 September 1973.

\section{INTRODUCTION}

Acetate is present in the circulating blood in appreciable concentrations only during ethanol metabolism, in which case the arterial concentration is fairly constant and within limits independent of the blood alcohol concentration (1). As ethanol is not metabolized in peripheral organs to any large extent, ingestion of small quantities of alcohol would appear to provide suitable conditions for the study of acetate utilization in the human body without interfering with acid-base metabolism (2).

In this study the question was examined whether working skeletal muscles utilize acetate.

\section{METHODS}

Six experiments were performed in five healthy, nonobese males (ages 21-25 yr). The informed consent of each subject was obtained. They were examined in the morning after a $14 \mathrm{~h}$ fast. With the subject in the supine position, a polyethylene catheter (ID $0.7 \mathrm{~mm}$ ) was inserted percutaneously $2-3 \mathrm{~cm}$ upstream in the brachial artery at the level of the humeral intercondylar line. A wide bore needle connected to a short collecting catheter was introduced $3-4 \mathrm{~cm}$ in the distal direction in the ipsilateral median cubital vein. During the investigation the catheters were kept patent by injections of saline. Heparin was not used.

After $30 \mathrm{~min}$ of rest arterial and venous blood samples were collected. Thereafter rhythmic forearm exercise was performed at a rate of 50 contractions $/ \mathrm{min}$ on an adjustable hand ergometer (3). The path of contraction was 30 $\mathrm{mm}$ and the ergometer was adjusted to work intensities of 
7, 10, and 15 kilopond-meters per minute ( $\mathrm{kpm} / \mathrm{min}$ ) by using different springs. From the 3 rd to the 7 th $\mathrm{min}$ of exercise, the hand was excluded from the circulation by a sphygmomanometer wrist cuff inflated to a pressure of $250 \mathrm{~mm} \mathrm{Hg}$. Arterial and venous blood samples were collected at the 4th and 6th min of exercise. During the 5th min, forearm blood flow was measured by a single injection indicator dilution technique (4). Arterial and venous blood samples were also taken during the resting periods.

After the control period the subjects were given about $25 \mathrm{~g}$ alcohol as beer, consumed within $10 \mathrm{~min}$. $40 \mathrm{~min}$ later the above-mentioned procedure was repeated at the same work intensity as before. In all but one subject a third period of exercise was performed 20 min later at a work load approximately $50 \%$ above that of the control study.

Oxygen saturation and hemoglobin were determined spectrophotometrically (5). Oxygen content was calculated assuming that $1 \mathrm{~g}$ of hemoglobin combines with $1.39 \mathrm{ml}$ $\mathrm{O}_{2}$. The following methods were used for determination of hematocrit (6), glucose (7), lactate (8), pyruvate (9), acetate (10), glycerol (11), FFA (12), and insulin (13) Acetate and FFA were measured in plasma, whereas other metabolites were estimated in whole blood deproteinized in ice-cold perchloric acid within 2 min after withdrawal. The pyruvate determinations were completed within $4 \mathrm{~h}$. Lactate, acetate, and FF.A determinations were made in duplicate, with other analyses being single determinations.

\section{RESULTS AND DISCUSSION}

Average values from all experiments are given in Table I.

The peroral administration of alcohol used here caused an increase in arterial plasma acetate concentration which was maintained at an essentially constant level throughout the experiment; the difference in concentration between the first and the second period of exercise was on average $0.02 \mathrm{mM}$ ranging from 0.00 to 0.03 excluding one experiment in which a difference of 0.35 $\mathrm{mM}$ was found. This experiment is included in the data of Table I.

Both at rest and during exercise there was a significant arteriovenous difference in plasma acetate $(0.24 \pm$ $0.04 \mathrm{mM}[n=5]$ and $0.23 \pm 0.06 \mathrm{mM}[n=6]$, respectively) indicating a net uptake of acetate. Such uptake of acetate in the forearm has also been observed by Jorfeldt. ${ }^{1}$

Since no attempt was made to measure blood flow at rest in the present study, the total uptake of acetate in the resting forearm tissues can only be estimated: Assuming a blood flow a rest of $5 \mathrm{ml} / \mathrm{min} / 100 \mathrm{ml}$ forearm tissue, the uptake of acetate can be calculated to about $1 \mu \mathrm{mol} / \mathrm{min} / 100 \mathrm{ml}$.

The acetate uptake in the forearm during exercise can be directly calculated using the arteriovenous difference and blood flow. The values for blood flow (and oxygen uptake) in the exercising forearm found in the present study agree well with those obtained by other investi-

\footnotetext{
${ }^{1}$ Personal communication.
}

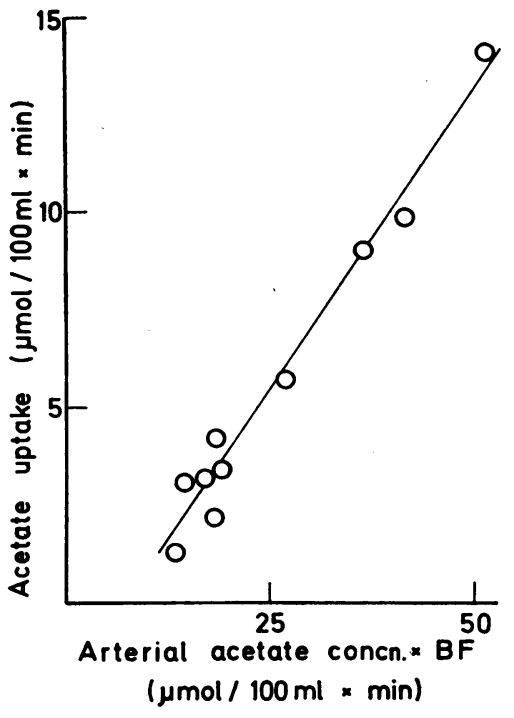

FIGURE 1 Relation of acetate uptake in the working forearm to the load offered (arterial acetate concentration times blood flow). The points represent five experiments with two working periods in each at different work intensities. Each point is the average of the two determinations made in each working period. The regression line is represented by the formula $y=0.30 x-2.33 ; r=0.98$.

gators at comparable work intensities $(3,14,15)$. The ingestion of ethanol caused no significant changes in these parameters.

In Fig. 1 the uptake of acetate during exercise is related to the load offered (arterial acetate concentration times blood flow). Within the limits examined there is a linear and significant correlation $(r=0.98)$. This correlation is closer than that found between acetate uptake and arterial acetate concentration $(r=0.77)$. Similar observations were made by Jorfeldt (15).

Owing to the fact that the extraction of acetate from the blood is fairly constant at rest and at all work levels, the uptake of acetate is for a given arterial acetate concentration proportional to the blood flow and thus more pronounced the higher the work load (Fig. 1). However, acetate metabolism seems to make up a constant proportion of total substrate metabolism. Assuming a $\mathrm{P} / \mathrm{O}$ ratio of 3 in the tissue and complete oxidation of acetate removed from the blood, the fraction of the energy production originating from oxidation of acetate can be calculated from the output of lactate and the consumption of oxygen and acetate. An average value of $6.5 \%$ is found. This may not be a valid figure for muscle tissue in general, since the contribution of acetate metabolism in the human heart during alcoholemia was calculated to be about $20 \%$ (2).

The reproducibility of the experiments is seen in Table II, which shows two similar experiments on the same subject. 
TABLE I

Average Results of Six Experiments with Five Subjects

\begin{tabular}{lccc}
\hline & $\begin{array}{c}\text { Control } \\
\text { period }\end{array}$ & $\begin{array}{c}\text { 1st ethanol } \\
\text { period }\end{array}$ & $\begin{array}{c}\text { 2nd ethanol } \\
\text { period }\end{array}$ \\
\hline Work intensity, $\mathrm{kpm} / \mathrm{min}^{*}$ & 7 & 7 & $7-15$ \\
Blood flow, $\mathrm{ml} / 100 \mathrm{ml} \times \mathrm{min} \ddagger$ & $28 \pm 2.5$ & $32 \pm 4.9$ & $41 \pm 5.6$ \\
Oxygen uptake, $\mu \mathrm{mol} / 100 \mathrm{ml} \times \mathrm{min}$ & $146 \pm 24$ & $139 \pm 33$ & $173 \pm 27$ \\
Acetate & & & \\
$\quad$ Arterial concn., $\mathrm{mM}$ & $-\S$ & $0.88 \pm 0.10$ & $0.81 \pm 0.09$ \\
$\quad$ Uptake, $\mu \mathrm{mol} / 100 \mathrm{ml} \times \mathrm{min}$ & - & $5.8 \pm 1.8$ & $5.8 \pm 1.6$ \\
Glucose & & & \\
$\quad$ Arterial concn., $\mathrm{mM}$ & $5.2 \pm 0.30$ & $7.9 \pm 0.36$ & $6.4 \pm 0.30$ \\
$\quad$ Uptake, $\mu \mathrm{mol} / 100 \mathrm{ml} \times \mathrm{min}$ & $4.0 \pm 1.6$ & $10.2 \pm 3.0$ & $5.6 \pm 1.7$ \\
Lactate & & & \\
Arterial concn., $\mathrm{mM}$ & $0.88 \pm 0.05$ & $1.57 \pm 0.11$ & $1.82 \pm 0.19$ \\
$\quad$ Output, $\mu \mathrm{mol} / 100 \mathrm{ml} \times \mathrm{min}$ & $72 \pm 25$ & $57 \pm 20$ & $59 \pm 20$ \\
Lactate/pyruvate & & & \\
$\quad$ Arterial blood & $18 \pm 1.3$ & $34 \pm 1.2$ & $33 \pm 3.5$ \\
$\quad$ Venous blood & $34 \pm 5.4$ & $44 \pm 6.4$ & $36 \pm 3.4$ \\
FFA, Arterial concn., $\mathrm{mM}$ & $0.69 \pm 0.08$ & $0.28 \pm 0.05$ & $0.30 \pm 0.07$. \\
Glycerol, Arterial concn., $\mu M$ & $79 \pm 8$ & $42 \pm 1$ & $44 \pm 3$ \\
\hline
\end{tabular}

Figures are given as mean \pm SEM. The arterial concentrations in the resting periods of the substances listed were the same as in the immediately following working period.

* In one subject the work intensity was $10 \mathrm{kpm} / \mathrm{min}$ in the control and 1 st ethanol period. In another subject the work intensity was $7 \mathrm{kpm} / \mathrm{min}$ in all three periods.

$\ddagger$ Blood flow is expressed per $100 \mathrm{ml}$ forearm. The volume of the forearm measured from the tip of the arterial catheter to the upper border of the wrist cuff averaged $1,460 \pm \mathrm{SD}$ $170 \mathrm{ml}$. The values given here for forearm blood flow are to be multiplied by 1.37 to convert to units of metabolic activity per $\mathrm{min} / 100 \mathrm{~g}$ muscle (24).

$\S$ The acetate concentration in the control periods was below $0.05 \mathrm{mM}$.

TABLE II

The Reproducibility of Results in the Same Subject

\begin{tabular}{|c|c|c|c|c|c|c|}
\hline & \multicolumn{2}{|c|}{ Control period } & \multicolumn{2}{|c|}{ 1st ethanol period } & \multicolumn{2}{|c|}{ 2nd ethanol period } \\
\hline & Exp. 1 & Exp. 2 & Exp. 1 & Exp. 2 & Exp. 1 & Exp. 2 \\
\hline Work intensity, $\mathrm{kpm} / \mathrm{min}$ & 7 & 7 & 7 & 7 & 10 & 10 \\
\hline Blood flow, $\mathrm{ml} / 100 \mathrm{ml} \times \min$ & 26.5 & 32.0 & 25.8 & 26.5 & 41.8 & 52.1 \\
\hline Acetate & 119 & 94 & 70 & 62 & 148 & 122 \\
\hline Arterial concn., $m M$ & - & 一 & 0.86 & 0.87 & 0.84 & 0.90 \\
\hline Uptake, $\mu \mathrm{mol} / 100 \mathrm{ml} \times \min$ & - & - & 3.2 & 2.2 & 5.7 & 9.0 \\
\hline \multicolumn{7}{|l|}{ Lactate } \\
\hline Arterial concn., $m M$ & 0.78 & 0.73 & 1.29 & 1.39 & 1.47 & 1.54 \\
\hline Output, $\mu \mathrm{mol} / 100 \mathrm{ml} \times \min$ & 28 & 32 & 14 & 15 & 27 & 35 \\
\hline \multicolumn{7}{|l|}{ Glucose } \\
\hline Arterial concn., $m M$ & 4.95 & 3.93 & 7.87 & 8.51 & 6.73 & 5.52 \\
\hline \multicolumn{7}{|l|}{ FFA } \\
\hline Arterial concn., $m M$ & 0.91 & 0.48 & 0.31 & 0.27 & 0.20 & 0.20 \\
\hline \multicolumn{7}{|l|}{ Glycerol } \\
\hline Arterial concn., $\mu M$ & 96 & 58 & 40 & 47 & 46 & 36 \\
\hline
\end{tabular}

The two experiments were performed at 4-wk intervals. The figures are average values of the two determinations made in each work period. For comments see footnotes to Table I. 
The presence of ethanol caused considerable changes in the concentration in the blood of glucose, lactate, FFA, and glycerol, which were similar in the resting and working periods (Table I). The glucose concentration showed a transient increase, probably caused by breakdown of residual glycogen in the liver in agreement with some earlier observations (cf. 16). Control experiments with three male subjects under conditions similar to those of the actual experiments showed an average blood glucose concentration of $5.2 \mathrm{mM}$ before and 5.8 and 5.0 , respectively, 40 and $70 \mathrm{~min}$ after consumption of lyophilized beer in appropriate amounts.

The arterial lactate concentration during the preethanol rest periods of $0.67 \mathrm{mM}$ rose to $1.53 \mathrm{mM}$ during the postethanol rest period, presumably because the utilization of lactate is decreased (17). A pronounced fall in the concentration of FFA was observed (Table I), a phenomenon which was studied by Crouse, Gerson, DeCarli, and Lieber (18) and ascribed to the presence of acetate. The glycerol concentration was also decreased, a result that confirms the finding of Feinman and Lieber (19). The concomitant fall in glycerol and FFA concentrations indicates reduced lipolysis in adipose tissues. However, the reduction in glycerol concentration is less than one-third of the decrease in FFA concentration. This may be a consequence of the inhibition of glycerol uptake by the liver caused by ethanol (20), but increased re-esterification of fatty acids in the adipose tissue cannot be ruled out. It should be added that changes in glucose, FFA, and glycerol similar to those reported here are observed only when small quantities of ethanol are given $(16,18,19)$. With larger loads or prolonged administration an entirely different pattern is seen.

Insulin was measured in arterial blood at rest and in the three working periods. The average concentrations in the six subjects were (microunits per milliliter serum) $11 \pm 3$ both in the pre-ethanol rest period and during the first (i.e., pre-ethanol) working period. In the consecutive periods with ethanol the insulin concentrations were $42 \pm 4.5$ and $30 \pm 3(n=5) \mu \mathrm{U} / \mathrm{ml}$ serum. Whether this moderate increase in insulin concentration is caused by the increased glucose concentration alone or whether a facilitation of insulin release has occurred under the influence of ethanol (21) is undecided. The increased insulin level may be partly responsible for the decrease in arterial FFA and glycerol concentrations.

The output of lactate from the working muscles decreased significantly in the presence of ethanol (Table I). The average output in the ethanol periods was 78 \pm $2.3 \%$ of the control values during work in the absence of ethanol. Similar results were obtained in the resting forearm by Kreisberg, Stanley, Rackley, and Russell (22). A decrease in the net output in the working fore- arm has also been observed after increasing arterial lactate concentrations by infusion of lactate (15). The changes in lactate metabolism are, therefore, probably unrelated to the simultaneous oxidation of acetate. The decrease in lactate output in the present experiments corresponds to only about one-fourth of the energy obtained from acetate oxidation.

The lactate/pyruvate concentration ratio $(\mathrm{L} / \mathrm{P})$ increased in the arterial blood after ingestion of alcohol by a factor of two during the working periods (Table I). During rest the values for arterial blood were 15 before and 31 after ethanol ingestion, compared with values for venous blood of 19 and 32, respectively. Thus the ratio in our experiments was not significantly changed when blood passed through the resting muscle tissue. During work, in the absence of ethanol, the venous $\mathrm{L} / \mathrm{P}$ was 34 , but showed relatively little further increase in the presence of ethanol in spite of the higher arterial $\mathrm{L} / \mathrm{P}$ ratio. This may indicate that the cytoplasmic NAD-mediated redox state in the working muscle in the presence of ethanol and acetate is very similar to that during normal conditions.

Glucose uptake in the working forearm seems to be higher during ethanol periods, presumably a consequence of the increased glucose and insulin concentrations (Table I). In the case of FFA and glycerol the arteriovenous differences were too uncertain to permit definite conclusions regarding possible lipolysis and fatty acid utilization in the exercising human forearm.

According to the above results, human skeletal muscle can use acetate as a substrate both at rest and during exercise. Furthermore it can be calculated that muscle probably accounts for the main part of total acetate elimination during alcoholemia. Using the arteriovenous difference obtained in this study and assuming that the total blood flow through the muscles is 4 liters/min during light work two-thirds of the acetate produced in the liver can be calculated to be metabolized in the muscles. However, this calculation implies that the arteriovenous difference for acetate is the same in all muscle groups. This assumption might, however, be wrong if acetate activation is rate limiting in muscle tissue (cf. 23).

\section{ACKNOWLEDGMENTS}

Insulin determinations were kindly performed by J. Rehfeld, M.D., Department of Clinical Chemistry, Bispebjerg Hospital.

This work was supported by grants from King Christian $X$ 's Foundation and the University of Odense.

\section{REFERENCES}

1. Lundquist, F. 1962. Production and utilization of free acetate in man. Nature (Lond.). 193: 579.

2. Lindeneg, O., K. Mellemgaard, J. Fabricius, and F. Lundquist. 1964. Myocardial utilization of acetate, lac- 
tate and free fatty acids after ingestion of ethanol. Clin. Sci. $(O x f$.). $27: 427$.

3. Wahren, J. 1966. Quantitative aspects of blood flow and oxygen uptake in the human forearm during rhythmic exercise. Acta Physiol. Scand. Suppl. 67: 269.

4. Trap-Jensen, J. 1970. Increased capillary permeability to ${ }^{131}$ iodide and $\left.{ }^{51} \mathrm{Cr}\right)$ EDTA in the exercising forearm of long-term diabetics. Clin. Sci. (Oxf.). 39: 39.

5. Holmgren, A., and B. Pernow. 1959. Spectrophotometric measurement of oxygen saturation of blood in the determination of cardiac output. A comparison with the van Slyke method. Scand. J. Clin. Lab. Invest. 11: 143.

6. Larsen, O. A., N. Tygstrup, and K. Winkler. 1963. The splanchnic hematocrit in man. Acta Physiol. Scand. 57: 397.

7. Slein, M. W. 1962. D-Glucose. In Methoden der Enzymatischen Analyse. H.-U. Bergmeyer, editor. VerlagChemie, Weinheim/Bergstr. 117.

8. Hohorst, H.-J. 1962. L(t)-Lactat. In Methoden der Enzymatischen Analyse. H.-U. Bergmeyer, editor. Verlag-Chemie, Weinheim/Bergstr. 266.

9. Bücher, Th., R. Czok, W. Lamprecht, and E. Latzko. 1962. Pyruvat. In Methoden der Enzymatischen Analyse. H.-U. Bergmeyer, editor. Verlag-Chemie, Weinheim/Bergstr. 253.

10. Lundquist, F. 1962. Acetat. In Methoden der Enzymatischen Analyse. H.-U.Bergmeyer, editor. VerlagChemie, Weinheim/Bergstr. 303.

11. Wieland, O. 1962. Glycerin. In Methoden der Enzymatischen Analyse. H.-U. Bergmeyer, editor. VerlagChemie, Weinheim/Bergstr. 211.

12. Duncombe, W. G. 1964. The colorimetric micro-determination of nonesterified fatty acids in plasma. Clin. Chim. Acta. 9: 122.

13. Ørskov, H. 1967. Wick-chromatography for the immunoassay of insulin. Scand. J. Clin. Lab. Invest. 20: 297.
14. Hagenfeldt, L., and J. Wahren. 1972. Human forearm muscle metabolism during exercise. VII. FFA uptake and oxidation at different work intensities. Scand. J. Clin. Lab. Invest. 30 : 429.

15. Jorfeldt, L. 1970. Metabolism of $\mathrm{L}(+)$-lactate in human skeletal muscle during exercise. Acta Physiol. Scand. Suppl. 338.

16. Lundquist, F. 1971. The metabolism of alcohol. In The biological Basis of Alcoholism. Y. Israel and J. Mardones, editors. John Wiley \& Sons, Inc., New York. 1.

17. Kreisberg, R. A., W. C. Owen, and A. M. Siegal. 1971. Ethanol-induced hyperlactacidemia. Inhibition of lactate utilization. J. Clin. Invest. 50: 166.

18. Crouse, J. R., C. D. Gerson, L. M. DeCarli, and C. S. Lieber. 1968. Role of acetate in the reduction of plasma free fatty acids produced by ethanol in man. J. Lipid Res. 9 : 509.

19. Feinman, L., and C. S. Lieber. 1967. Effect of ethanol on plasma glycerol in man. Am. J. Clin. Nutr. 20: 400.

20. Lundquist, F., N. Tygstrup, K. Winkler, and K. B. Jensen. 1965. Glycerol metabolism in human liver: inhibition by ethanol. Science (Wash. D. C.). 150: 616.

21. Metz, R., S. Berger, and M. Mako. 1969. Potentiation of the plasma insulin response to glucose by prior administration of alcohol. An apparent islet-priming effect. Diabetes. 18 : 517.

22. Kreisberg, R. A., A. W. Stanley, C. E. Rackley, and R. O. Russell. 1972. Human skeletal muscle lactate metabolism. Effect of ethanol. Diabetes. 21: 367.

23. Ballard, F. J. 1972. Supply and utilization of acetate in mammals. Am. J. Clin. Nutr. 25: 773.

24. Andres, R., G. Cader, and K. L. Zierler. 1956. The Quantitatively minor role of carbohydrate in oxidative metabolism by skeletal muscle in intact man in the basal state. Measurements of oxygen and glucose uptake and carbon dioxide and lactate production in the forearm. $J$. Clin. Invest. 35 : 671 